Article

\title{
Carbon Offset Service and Design Guideline of Tree Planting for Multifamily Residential Sites in Korea
}

\author{
Hyun-Kil Jo ${ }^{1}$, Hye-Mi Park ${ }^{2, *}$ and Jin-Young Kim ${ }^{2}$ \\ 1 Department of Ecological Landscape Architecture Design, Kangwon National University, \\ Chuncheon 24341, Korea \\ 2 Department of Landscape Architecture, Graduate School, Kangwon National University, \\ Chuncheon 24341, Korea \\ * Correspondence: phm2071@gmail.com
}

Received: 13 May 2019; Accepted: 22 June 2019; Published: 27 June 2019

check for updates

\begin{abstract}
Multifamily residential sites (MRS) are practical alternatives for securing a carbon uptake source in urban areas where hardscape is dominant, as trees must be planted in the lot area, according to the current landscape-related ordinances in Korea. Tree planting contributes to sustainability of residential sites through carbon reduction. This study quantified direct and indirect carbon reduction from tree planting in MRS in Korea and explored sustainable design guidelines to maximize the carbon offset service of MRS. The total annual direct and indirect carbon reduction through tree planting in all the MRS was estimated to be about $101.1 \mathrm{kt} /$ year. This carbon reduction equaled 3.3\% of the total annual carbon emissions from the heating and cooling energy consumption of multifamily buildings. This study considered both direct and indirect carbon reduction from trees in MRS which was insufficient in previous studies. The results of this study can be useful internationally by sharing the information of sustainable residential design in enhancing carbon offset service.
\end{abstract}

Keywords: carbon reduction; building energy saving; urban tree; design model; ecological service; tree planting structure

\section{Introduction}

Climate change may lead to adverse effects on natural ecosystems and socio-economic systems, such as a reduction in biodiversity, rising sea levels, decreasing agricultural productivity, and extreme weather events [1]. International society has promoted various international treaties to fight critical climate change, and the Paris Climate Agreement has been signed to assign the obligation of greenhouse gas (GHG) emission reductions to every country in order to limit the rise in the Earth's average temperature to $1.5^{\circ} \mathrm{C}$ [2]. $\mathrm{CO}_{2}$ is the most significant GHG contributing to climate change. The global $\mathrm{CO}_{2}$ concentration in 2017 averaged approximately $405 \mathrm{ppm}$, an increase of $45 \%$ compared with the $\mathrm{CO}_{2}$ concentration prior to the Industrial Revolution [3,4], and this is expected to increase to $650 \mathrm{ppm}$ by 2050 [5]. The global $\mathrm{CO}_{2}$ emissions in 2016 were 32,316 Mt/year, representing an increase of $57 \%$ compared with the emissions in 1990 [6].

The global urban areas where carbon emission activities occur totaled $602,864 \mathrm{~km}^{2}$ in 2000 , representing an increase of approximately four times compared with the global urban areas prior to the Industrial Revolution [7]. Residential land is one of the major land use types (40-50\% of urban areas) in urban land [8,9]. The energy consumption of residential sites accounts for $45-55 \%$ of total building energy consumption $[10,11]$. To reduce the carbon emissions of residential sites, energy conservation, the development of renewable energy, and tree planting are required. In particular, tree planting is effective for reducing the atmospheric carbon level in a short period of time. Trees planted in residential sites contribute to carbon reduction in two ways: By directly sequestering carbon through 
photosynthesis (direct carbon reduction) and by avoiding carbon emissions through building energy savings (indirect carbon reduction). In addition, according to the 2005 Kyoto Protocol to the United Nations Framework Convention on Climate Change and the 2006 Intergovernmental Panel on Climate Change (IPCC) guidelines, revegetation in settlements with an area of $500 \mathrm{~m}^{2}$ or more is recognized as an activity that improves carbon uptake sources $[12,13]$, and tree planting in residential sites can be acceptable for this category of activity.

As the importance of carbon reduction through tree planting in residential sites has been recognized, related studies have been conducted [14-21]. Akbari et al. [14] analyzed cooling energy savings by shade trees in two detached residential sites (DRS) in Sacramento. A 25\% increase in tree cover was estimated to reduce cooling energy consumption by $17 \%$ in Phoenix, $25 \%$ in Lake Charles, and $57 \%$ in Sacramento [15]. Jo and McPherson [16] quantified the avoidance of carbon emissions due to energy saving by trees in DRS in Chicago and suggested planting strategies to maximize indirect carbon reduction. Donovan and Butry [17] reported that planted trees in the west of a house can reduce carbon emissions from summertime electricity consumption by $31 \%$. In hot arid climates, shade trees in residential sites can reduce the use of cooling energy by up to $0.37 \mathrm{MWh} /$ year compared with the absence of shade trees [18]. Most of these studies have focused on estimating the energy savings of DRS at the house or city scale.

Few studies have estimated the energy savings and carbon reduction of residential sites, including multifamily residential sites (MRS) and DRS [19,20]. Jo et al. [19] reported that tree planting in all residential sites in Chuncheon, Korea, saved annual heating energy by $2.2 \%$ and cooling energy by $8.8 \%$ through shading, evapotranspiration, and windspeed reduction. These heating and cooling energy savings reduced carbon emissions by 3\% annually. The urban and community trees in the US lowered residential energy consumption by $7.2 \%$ annually and reduced $\mathrm{CO}_{2}$ emissions from energy savings by approximately $43,820 \mathrm{kt}$ [20]. However, the above-mentioned studies only estimated indirect carbon reduction from energy saving of residential trees. The annual direct carbon reduction by existing trees in MRS in Sydney was approximately $2.2 \mathrm{t} / \mathrm{year}$ [21]. The carbon offset service of tree planting in residential sites needs to be estimated considering both direct and indirect carbon reduction. However, there is little research that estimates both the direct and indirect carbon reduction of residential trees worldwide. In addition, the appropriate design guidelines regarding residential sites are required to maximize carbon offset service, since carbon reduction in residential sites differs depending on orientation, density, species, dimensions, and the vertical structure of planted trees $[16,17,19,22]$.

In Korea, where $\mathrm{CO}_{2}$ emissions are the sixth-highest worldwide, the predominant type of land use in urban areas (all land use types except natural land) is residential land (64\%) [23]. Of the percentage of dwelling types in Korea, MRS account for $50 \%$ of all residences, which is the most common, followed by DRS (33\%) [24]. Since the 1960s, the number of MRS has increased rapidly in Korea due to overpopulation in urban areas caused by industrialization. Whereas the average number of floors of MRS was five stories in the 1960s, MRS are becoming higher and denser. The MRS where the floor area ratio is high and in which most of the urban population lives consume a large amount of energy every year, significantly increasing carbon emissions in urban areas. On the other hand, MRS are becoming a practical alternative for securing carbon uptake sources in urban areas where greenspace is limited because a tree must be planted in some part of the lot area due to landscape-related ordinances in Korea.

However, as mentioned previously, there is little information about the carbon reduction of tree planting in MRS and low carbon design of MRS not only in Korea but also globally. The carbon offset service from residential trees could vary significantly among nations based on differences of climates, tree planting structures, and energy uses. Diverse studies by region, nation, and dwelling type will contribute to our understanding of carbon offset service with residential trees. Thus, the purpose of this study was to quantify the carbon offset service, including both direct and indirect carbon reductions from tree planting, and to suggest sustainable design guidelines for MRS in Korea. The results of this study could be useful internationally by sharing the information of sustainable residential design 
in enhancing carbon offset service as there is a lack of research regarding carbon reduction by trees in MRS.

\section{Materials and Methods}

\subsection{Study Framework}

The study consisted of six phases: Selection of study cities; sampling of study MRS in the selected cities; field survey of planting trees in study MRS; collection of data on building characteristics and energy consumption of all MRS in Korea; estimation of carbon offset service; and exploring design guideline to enhance the carbon offset service of MRS. Figure 1 explains the framework and procedure of this study. The Korea was selected because there is little information on carbon offset service associated with residential trees, while MRS are dominant in urban areas.

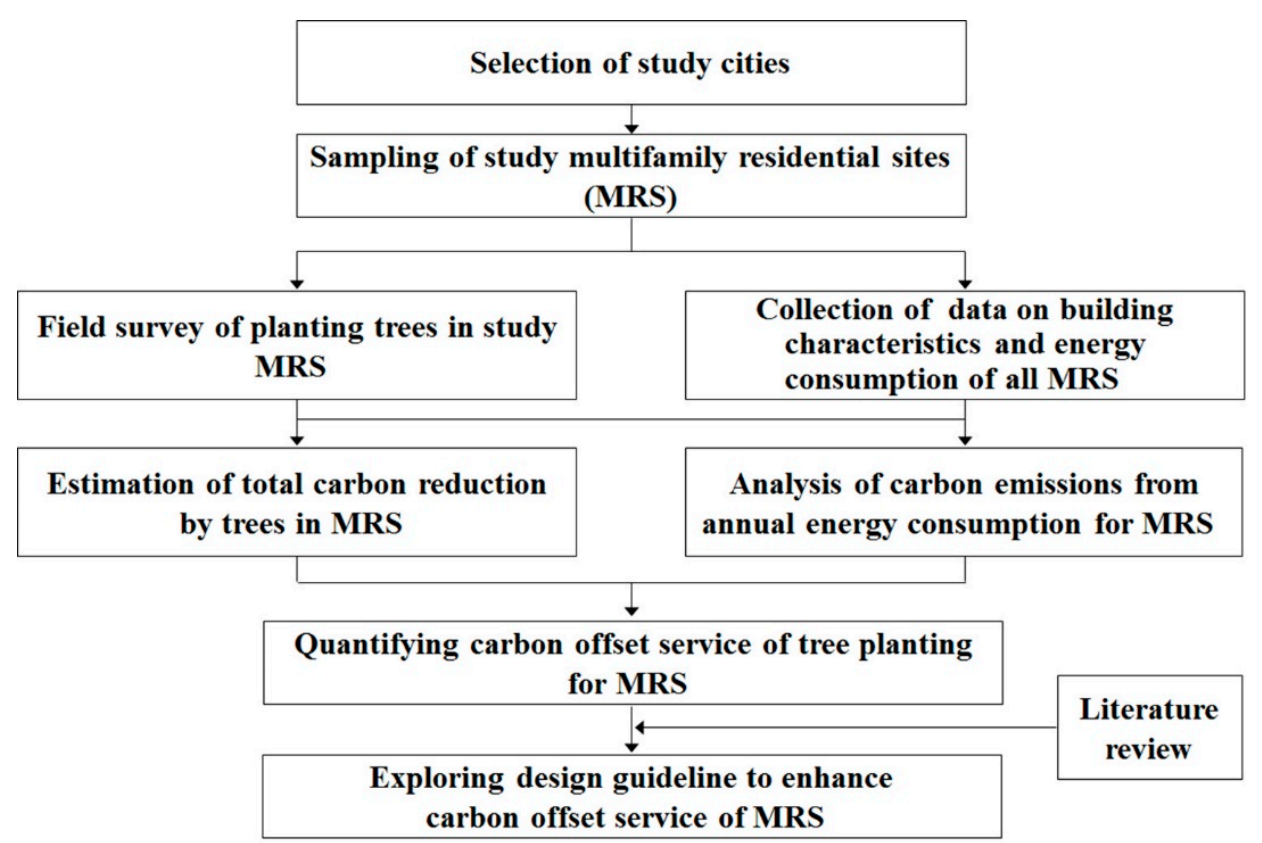

Figure 1. Systematic study flowchart.

\subsection{Selection of Study Cities}

The cities examined in this study were selected by considering the regional distribution to quantify the carbon offset service and tree planting structure of the MRS in Korea. The cities selected for the study included Seoul (the capital of south Korea, located in the north), Daejeon (located in the middle), and Daegu (located in the south) (Figure 2). In Korea, these are capital or metropolitan cities and represent the typical urban landscape dominated by MRS. MRS were surveyed in this study because they are the largest distributed residential dwelling type in Korea (50\%) [24], they have a large annual energy consumption, and because a planting space can be more easily secured for MRS than for DRS. Based on the current landscape-related ordinances in Korea, no planting is required within a residential lot smaller than $200 \mathrm{~m}^{2}$ [25]. According to Jo [26], residences smaller than $200 \mathrm{~m}^{2}$ in the lot area account for approximately $50 \%$ of the total detached residences in the middle of Korea. Thus, most DRS have no trees. 


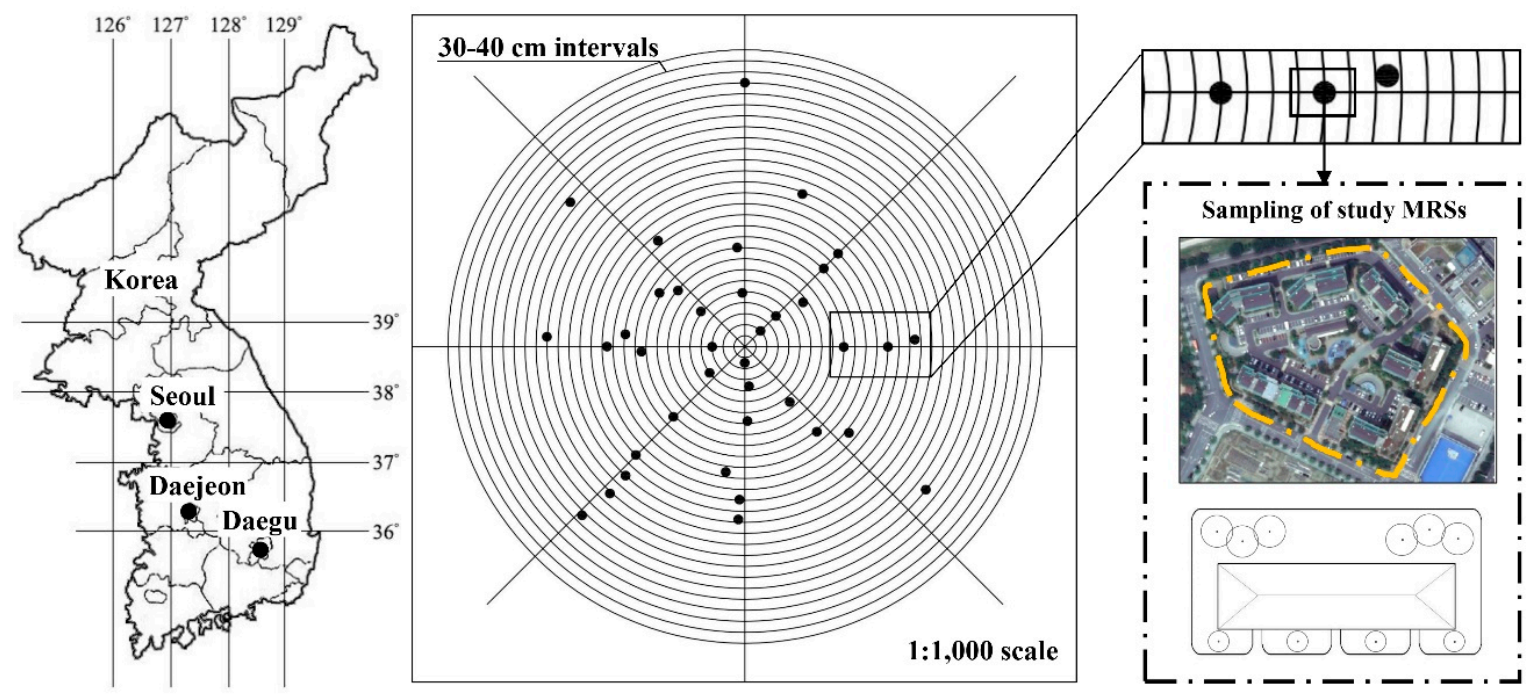

Figure 2. Location of three study cities and systematic random sampling method used in this study.

A total of 110 sample MRS (36 for Seoul, 38 for Daejeon, and 36 for Daegu) were selected for the study by applying the systematic random sampling method to a 1:1000-scale aerial photograph (Figure 3). Specifically, eight evenly spaced straight lines radiating from the centers of the study cities were drawn and based on the city size and MRS distribution, looping circles were plotted at $40 \mathrm{~cm}$ intervals for Seoul and Daejeon and at $30 \mathrm{~cm}$ intervals for Daegu. Then, the MRS located at the intersections of the lines and the circles or at the shortest distance from these intersections were selected for this study. This sampling design is a useful method for sampling MRS randomly on a city-wide scale, avoiding selection bias [27]. The number of samples was determined based upon a compromise between the competing concerns for data reliability and cost availability.

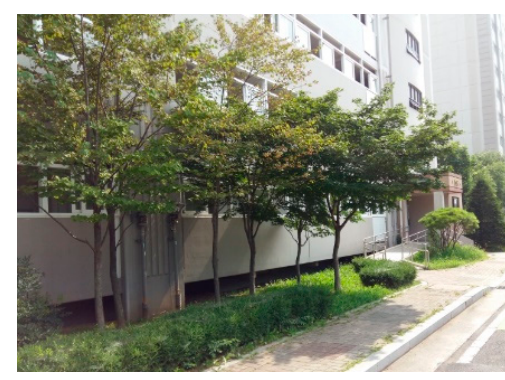

(a). planting space

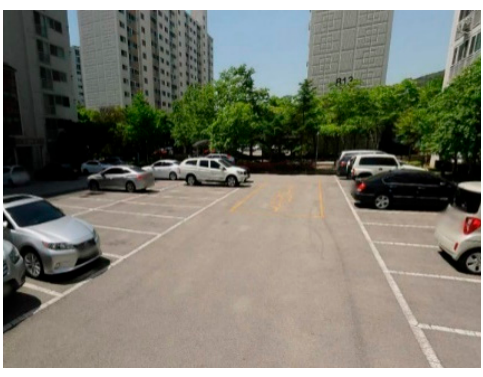

(b). parking lot

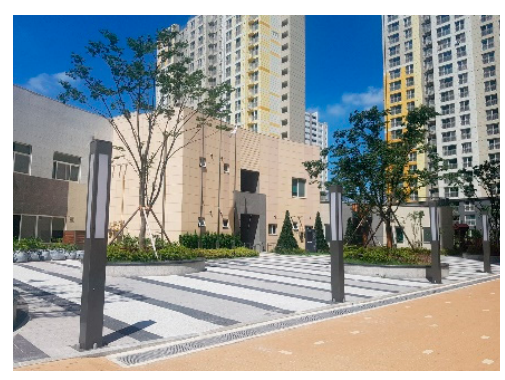

(c). square

Figure 3. Typical landscape of study multifamily residential sites.

\subsection{Field Survey and Analysis}

In this study, a field survey was carried out for all of the existing trees in each of the selected MRS with the residents' approval, and the total lot area and areal distribution of the land cover types (buildings, pavements and facilities, trees and shrubs, grass and bare soil) of the study MRS were measured. The field survey tree data included the species, height, crown width, stem diameter at a breast height of $1.2 \mathrm{~m}(\mathrm{dbh})$ for trees and at a height of $15 \mathrm{~cm}$ above ground for shrubs $(2 \mathrm{~cm}$ or less in dbh), vertical structures, and size of the planting space. Moreover, potential planting spaces that could accommodate newly planted trees with a crown width of $2 \mathrm{~m}$ or wider and height of $3 \mathrm{~m}$ or higher in a permeable area unoccupied by various facilities (utility lines, manholes, and septic tanks) were measured. These survey data were used to analyze the density and cover per unit area, dbh distribution, and importance values of tree and shrub species. The collected data were also used to compute the annual direct and indirect carbon reduction by the trees in each of the study MRS. 


\subsection{Estimation of Carbon Offset Service}

Trees planted in MRS can reduce atmospheric carbon in two ways: By directly sequestering carbon through photosynthesis (direct carbon reduction) and by avoiding carbon emissions through building energy savings (indirect carbon reduction). Annual direct carbon reduction by urban trees can differ from that by forest-grown trees due to management input and less competition. Therefore, this study estimated the annual direct carbon uptake by residential trees using quantitative models developed for the urban open-grown trees of each species [26,28-34] (Table 1). These quantitative models in which the stem diameter was the most important independent variable were derived from either seasonal $\mathrm{CO}_{2}$ exchange rate measurements or the direct harvesting method of urban trees. In cases of tree species for which a quantitative model was unavailable, regression models of the same genus or group were used to compute the average carbon estimates. The mean direct carbon reduction per unit of MRS area and per crown cover was calculated for the surveyed area and tree cover. The carbon uptake per unit of MRS area was then applied to compute the total annual direct carbon reduction of the entire MRS area [35] in Korea. In this study, carbon uptake refers to the annual rate of carbon absorption by trees.

Table 1. Quantitative model sources used to calculate carbon uptake of tree and shrub species in the study multifamily residential sites.

\begin{tabular}{|c|c|c|c|}
\hline & Species & Diameter Range $^{\text {a }}(\mathrm{cm})$ & Reference \\
\hline \multirow[t]{16}{*}{ Tree } & Abies holophylla & 5-19 & Jo et al., 2014 \\
\hline & Acer palmatum & $7-27$ & Jo and Cho, 1998 \\
\hline & " & $5-20$ & Jo and Ahn, 2012 \\
\hline & Chionanthus retusus & $3-11$ & Jo et al., 2014 \\
\hline & Cornus officinalis & $3-15$ & Jo et al., 2014 \\
\hline & Ginkgo biloba & $6-31$ & Jo and Cho, 1998 \\
\hline & " & $5-25$ & Jo and Ahn, 2012 \\
\hline & Pinus densiflora & $5-29$ & Jo and Ahn, 2001; Jo et al., 2013 \\
\hline & Pinus koraiensis & $5-33$ & Jo and Ahn, 2001; Jo et al., 2013 \\
\hline & Platanus occidentalis & $10-58$ & Jo and Cho, 1998 \\
\hline & Prunus yedoensis & $5-23$ & Jo and Ahn, 2012 \\
\hline & Taxus cuspidata & $2-15$ & Jo et al., 2014 \\
\hline & Zelkova serrata & $6-34$ & Jo and Cho, 1998 \\
\hline & $"$ & $5-28$ & Jo and Ahn, 2012 \\
\hline & General hardwoods & $3-28$ & Jo, 2017 \\
\hline & General softwoods & $5-31$ & Jo, 2017 \\
\hline \multirow[t]{5}{*}{ Shrub } & Pinus spp. & $0.6-3.5$ & Jo, 2002 \\
\hline & Quercus spp. & $0.5-4.0$ & Jo, 2002 \\
\hline & Rhododendron spp. & $0.4-3.4$ & Jo, 2002 \\
\hline & General hardwoods & $0.4-4.0$ & Jo, 2001; 2002 \\
\hline & General softwoods & $0.4-4.0$ & Jo, 2001; 2002 \\
\hline
\end{tabular}

(a) Stem diameter at breast height of $1.2 \mathrm{~m}$ for trees and diameter at $15 \mathrm{~cm}$ above ground for shrubs.

Annual indirect carbon reduction was quantified based on a carbon estimate per unit of conditioned floor area (CFA) by trees planted in multifamily buildings; that is, the annual energy saving per CFA was calculated by applying the annual total heating and cooling energy consumption [36-38], the total CFA [39], and the ratio of energy saving per CFA by trees [19] to the MRS in Korea. These energy savings were converted into the carbon emission reduction using the carbon emission coefficient per energy source $[40,41]$, such as oil, gas, and electricity. In addition, the total indirect carbon reduction in all MRS in Korea was calculated by multiplying the carbon emission reduction per CFA by the total CFA for up to two floors because, considering the mean height $(6.6 \mathrm{~m})$ of the planted trees in the study MRS, it is clear that only the first two floors benefit from energy savings due to trees.

The total carbon reduction of the entire MRS was calculated by summing the direct and indirect carbon reduction. In addition, the carbon offset service by the trees planted in MRS was quantified compared with the carbon emissions according to the annual heating and cooling energy consumption 
of the MRS. Based on the above results and review of the literature, this study explored sustainable design guidelines for enhancing the carbon offset service of tree planting in MRS.

\section{Results and Discussion}

\subsection{Land Cover Types}

The total area and resident population of the MRS in the study cities were 14,215 ha (Seoul: 9975 ha, Daejeon: 1813 ha, and Daegu: 2427 ha) and 6,940,000 people (Seoul: 4,581,123, Daejeon: 910,459, and Daegu: 1,451,045), accounting for $28 \%$ and $51 \%$ of the total area and resident population of the MRS in Korea, respectively [24]. The area of the study MRS ranged from 0.2 to 15.7 ha. The study MRS with an area of less than 3 ha accounted for $60 \%$ of all of the study MRS, comprising the largest proportion, followed by $3-6$ ha $(28.1 \%)$ and 6 ha or larger (11.9\%). The total surveyed area of the study MRS was 422.3 ha (Table 2), which accounted for approximately $3 \%$ of the total MRS area of the study cities. The average number of floors and the floor area ratio in the study MRS were 15 stories and $250 \%$, respectively. The resident density of the study MRS ranged from 161 to 1209 persons/ha.

Table 2. Total area and building density of multifamily residential sites (MRS) sampled in study cities ${ }^{\mathrm{a}}$.

\begin{tabular}{ccccccc}
\hline City & N & Total Area (Ha) & $\begin{array}{c}\text { Building } \\
\text { Area (Ha) }\end{array}$ & Floor Area Ratio & Residents & $\begin{array}{c}\text { Resident Density } \\
\text { (Persons/Ha) }\end{array}$ \\
\hline Seoul & 36 & 140.1 & 28.9 & 261 & 87,590 & 613.0 \\
Daejeon & 38 & 156.0 & 35.9 & 240 & 87,133 & 572.9 \\
Daegu & 36 & 126.2 & 35.3 & 256 & 81,001 & 632.7 \\
\hline
\end{tabular}

(a) Source: Korean Statistical Information Service [24]. (b) Resident density was calculated by dividing residents by area of MRS.

The percentage of land cover types in the study MRS averaged $57.7 \pm 1.3 \%$ for pavements and facilities, $23.7 \pm 1.0 \%$ for buildings, $17.9 \pm 1.2 \%$ for trees and shrubs, and $0.7 \pm 0.0 \%$ for grass and bare soils (Table 3). Thus, the study MRS were composed mostly of impervious areas such as pavements, facilities, and buildings. Most of the pavements and facilities were parking lots, roads, and large squares with no specific purpose of use. Kim [42] reported that the ratio of impervious areas of the residential sites in Roanoke, USA was approximately $25.9 \%$. Compared to this value, the impervious areas of the study MRS were about three times higher. To improve the carbon offset service of the MRS, it would be desirable to expand the planting areas by reducing the amount of unnecessary impervious areas.

Table 3. Percentage of land cover types in study multifamily residential sites.

\begin{tabular}{ccccc}
\hline \multirow{2}{*}{ City } & \multicolumn{4}{c}{ Land Cover Type (\%) } \\
\cline { 2 - 5 } & Paving/Facility & Building & Tree/Shrub & Grass/Bare Soil \\
\hline Seoul & $59.3 \pm 3.1$ & $25.2 \pm 1.5$ & $15.1 \pm 3.0$ & $0.4 \pm 0.0$ \\
Daejeon & $59.0 \pm 2.2$ & $23.0 \pm 1.6$ & $17.0 \pm 2.0$ & $1.0 \pm 0.3$ \\
Daegu & $55.2 \pm 1.8$ & $23.2 \pm 1.4$ & $21.1 \pm 1.5$ & $0.5 \pm 0.0$ \\
Total & $57.7 \pm 1.3$ & $23.7 \pm 1.0$ & $17.9 \pm 1.2$ & $0.7 \pm 0.0$ \\
\hline
\end{tabular}

\subsection{Tree Planting Characteristics}

The planting density of trees was in the $0.2-5.5$ trees $/ 100 \mathrm{~m}^{2}$ range and varied between the different MRS surveyed in this study. The density of $<2$ trees $/ 100 \mathrm{~m}^{2}$ comprised $45.0 \%$ of all study MRS, followed by $2-3$ trees $/ 100 \mathrm{~m}^{2}(43.4 \%)$ and $\geq 4$ trees $/ 100 \mathrm{~m}^{2}(11.6 \%)$. The mean tree density for the study MRS was $2.5 \pm 0.1$ trees $/ 100 \mathrm{~m}^{2}$ (Table 4 ), which was slightly lower than the 2.8 trees $/ 100 \mathrm{~m}^{2}$ of the residential sites in Roanoke, USA [42]. 
Table 4. Density, basal area, and cover of existing trees in study multifamily residential sites.

\begin{tabular}{|c|c|c|c|}
\hline City & $\begin{array}{c}\text { Density } \\
\left(\text { Tree/100 } \mathrm{m}^{2}\right)\end{array}$ & $\begin{array}{c}\text { Basal Area } \\
\left(\mathrm{cm}^{2} / 100 \mathrm{~m}^{2}\right)\end{array}$ & $\begin{array}{c}\text { Cover }^{a} \\
(\%)\end{array}$ \\
\hline Seoul & $1.9 \pm 0.1$ & $457.3 \pm 54.1$ & $21.9 \pm 1.5$ \\
\hline Daejeon & $2.7 \pm 0.2$ & $483.1 \pm 42.8$ & $23.1 \pm 2.0$ \\
\hline Daegu & $2.8 \pm 0.2$ & $453.8 \pm 31.0$ & $23.9 \pm 1.6$ \\
\hline Total & $2.5 \pm 0.1$ & $465.4 \pm 24.4$ & $23.0 \pm 1.0$ \\
\hline
\end{tabular}

The basal area of the planted trees ranged from 28.5 to $1322.6 \mathrm{~cm}^{2} / 100 \mathrm{~m}^{2}$ with an average of $465.4 \pm 24.4 \mathrm{~cm}^{2} / 100 \mathrm{~m}^{2}$. A total of $54.2 \%$ of all study MRS had $<400 \mathrm{~cm}^{2} / 100 \mathrm{~m}^{2}$. The mean basal area was quite similar among the study cities. The $\mathrm{dbh}$ of the trees averaged $13.6 \pm 0.1 \mathrm{~cm}$ across all study MRS. The trees with a dbh of $<20 \mathrm{~cm}$ accounted for $81.6 \%$ of all planted trees, which was the most (Figure 4). A previous study showed that in some residential sites in the UK, trees with a dbh of $<20 \mathrm{~cm}$ comprised approximately $50 \%$ of planted trees [43]. Thus, the distribution of small trees in the study MRS was about 1.6 times higher than that in the UK.

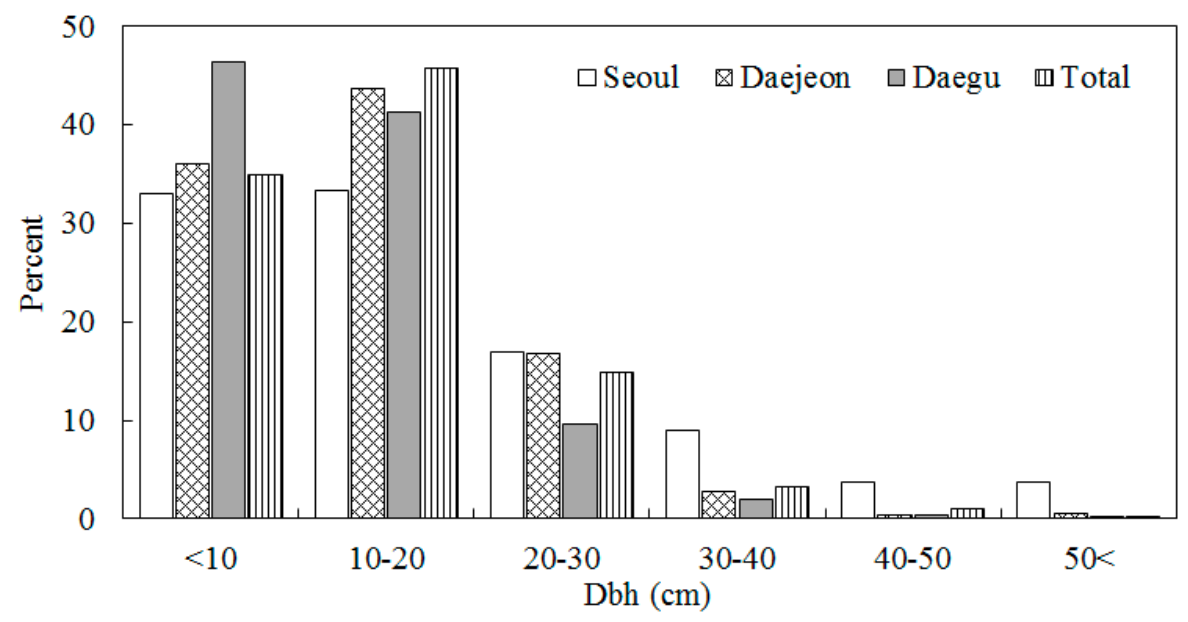

Figure 4. Diameter at breast height (dbh) distribution of trees planted in the study multifamily residential sites.

The average cover of the planted trees and shrubs was $23.0 \pm 1.0 \%$, ranging from a minimum of $4.3 \%$ to a maximum of $48.4 \%$. The tree and shrub cover of $20-40,<20$, and $>40 \%$ comprised 54.4 , 39.8 , and $5.8 \%$, respectively. There were no significant differences ( $95 \%$ confidence level) in the tree and shrub cover among the study cities. The tree cover of some residential sites in the USA and Australia ranged from 30.4 to $31.4 \%$ [42,44]. Compared to these values, the tree cover of the study MRS (19.2\% excluding shrubs) was lower by $11.2-12.2 \%$.

A total of 197 tree and shrub species were found in the study MRS, indicating a diverse composition of species. The dominant tree and shrubs species in the study MRS (based on the importance values) were Zelkova serrata, Acer palmatum, Pinus densiflora, Prunus yedoensis, Rhododendron yedoense var. poukhanense, and Buxus microphylla var. koreana. They are major landscape tree species that are typically highly dominant in most cities of the Korea [26,27,45,46].

The vertical structures of tree planting in MRS exhibited multi-layered structures in which an overlap of upper (tree) and lower (shrub) layers accounted for $75.1 \%$ of the total planted area, whereas single-layered structures of only the upper or lower layer comprised $24.9 \%$. The single-layered areas were mostly areas with trees $(21.4 \%)$, and a much smaller area was found to be covered by shrubs $(2.6 \%)$ and grass $(0.9 \%)$. Multi-layered structures from natural forests, in which there is an overlap of upper (large trees), middle (large shrubs and small trees), and lower layers (herbs and small shrub) 
would increase carbon storage per unit area [26]. This planting structure is effective in maximizing carbon uptake in urban areas with limited planting space. However, the vertical structure of the study MRS consisted only of upper and lower layers, and there were no middle layers. To improve the carbon reduction of MRS in the future, it would be desirable to apply multi-layered structures of upper, middle, and lower layers. The potential planting area in the study MRS was approximately $1.5 \mathrm{ha}$, in which about 4700 trees with a crown width of $2 \mathrm{~m}$ could be additionally planted.

\subsection{Carbon Offset Service}

The annual direct carbon reduction per unit area by the planted trees in the study MRS ranged from 0.3 to $2.9 \mathrm{t} / \mathrm{ha}$ /year with an average of $1.1 \pm 0.1 \mathrm{t} / \mathrm{ha} /$ year (Figure 5). The annual carbon uptake per unit area of some residential sites in the US and Australia were $2.2 \mathrm{t} / \mathrm{ha} /$ year and $2.3 \mathrm{t} / \mathrm{ha}$ /year, respectively [21,42]. The direct carbon reduction in the study MRS was only $50 \%$ of the estimated values, which was due to the differences in the density, size, and growth rate of the trees planted. The annual direct carbon reduction per unit of crown cover of the planted trees in the study MRS ranged from 0.2 to $0.9 \mathrm{~kg} / \mathrm{m}^{2} /$ year with an average of $0.5 \pm 0.0 \mathrm{~kg} / \mathrm{m}^{2} /$ year. Currently, no information is available regarding the direct carbon reduction indicator per unit of tree cover in the MRS. The urban land average carbon uptake per unit of tree cover in Korea was $0.5 \mathrm{~kg} / \mathrm{m}^{2} /$ year [26]. The average direct carbon reduction per unit of tree cover in the study MRS was similar to the estimates for entire cities. There were no differences (95\% confidence level) in the direct carbon reduction per unit area and tree cover among the study cities.

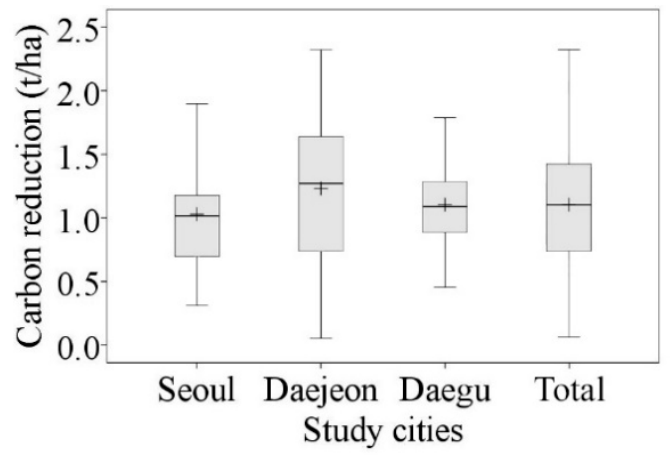

(a)

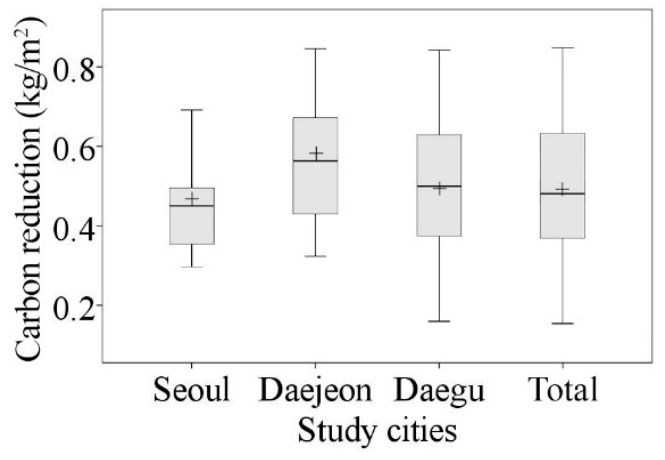

(b)

Figure 5. (a). Annual direct carbon reduction per area; (b). Annual direct carbon reduction per tree cover. Annual direct carbon reduction by trees and shrubs planted in study multifamily residential sites.

The annual heating and cooling energy savings by the planted trees per CFA of the MRS were $17.3 \mathrm{MJ} / \mathrm{m}^{2} /$ year and $0.7 \mathrm{kWh} / \mathrm{m}^{2} /$ year, respectively, due to shading, evapotranspiration, and windspeed reduction. The annual indirect carbon reduction per unit of CFA, building, and tree cover due to heating and cooling energy saving by residential trees was $330.3 \mathrm{~g} / \mathrm{m}^{2} /$ year, $384.4 \mathrm{~kg} /$ year, and $0.4 \mathrm{~kg} / \mathrm{m}^{2} /$ year, respectively. Jo et al. [19] reported that the carbon emission reduction per CFA of the MRS in Chuncheon was $462.1-974.8 \mathrm{~g} / \mathrm{m}^{2} /$ year depending on the differences in tree cover. Due to the changes in the heating facilities and carbon emission coefficients of Korean MRS, the indirect carbon reduction obtained in this study was smaller than that of previous studies. The primary heating fuels of the MRS in the 1990s were oil and liquefied petroleum gas (LPG), while liquefied natural gas (LNG) has been used more recently. Based on the energy saving estimates per CFA of the MRS, tree planting at MRS in Korea annually saved 2,305,234 GJ/year of heating energy and 89,683 MWh/year of cooling energy. These energy savings are equivalent to $\$ 39$ million/year of heating and cooling energy cost savings based on the residential LNG $(\$ 0.02 / \mathrm{MJ})[47]$ and electricity prices $(\$ 0.01 / \mathrm{kWh})[48]$ in Korea.

The total annual direct and indirect carbon reduction by the planted trees in all the MRS in Korea was estimated to be approximately $101.1 \mathrm{kt} / \mathrm{year}$ (direct: $56.9 \mathrm{kt} / \mathrm{year}$, indirect: $44.1 \mathrm{kt} / \mathrm{year}$ ). This carbon 
reduction equaled $3.3 \%$ of the total annual carbon emissions from the heating and cooling energy consumption of multifamily buildings in Korea. The cost of carbon capture and storage was reported to be approximately $\$ 116 / t /$ year [49]. Based on this cost, the economic value of the carbon reduction by MRS trees was equivalent to approximately $\$ 12$ million/year. When the heating and cooling energy saving cost (\$39 million/year) is also taken into account, tree planting in the MRS provides an economic benefit of approximately $\$ 51$ million/year. The per capita carbon emissions from residential electricity consumption amounted to $163.3 \mathrm{~kg} /$ year [50]. The planted trees in all of the MRS annually offset the amount of carbon emitted by approximately 620,000 persons. Thus, trees in the MRS play an important role in reducing the atmospheric carbon concentration in urban environments with limited greenspace.

\subsection{Sustainable Design Guideline}

MRS are key resources that can practically secure carbon uptake sources in urban areas that have limited greenspace, because tree planting is required within an MRS by the current landscape-related ordinances in Korea. However, the carbon offset service by the trees in the MRS has been limited due to the presence of large impervious areas (including parking lots, roads, and squares), narrow planting space around the building, lack of consideration of planting technique for building energy saving, and the predominance of small trees. Thus, it is necessary to establish sustainable design guidelines to enhance the carbon offset service by tree planting in MRS by overcoming the above-mentioned problems.

To maximize the building energy savings and carbon reduction in MRS, the following design guidelines including planting and building layout are suggested (Figures 6 and 7). Here, the length, width, and number of floors for the building were assumed to be approximately $56 \mathrm{~m}, 11 \mathrm{~m}$, and 15 stories, respectively, based on the average dimensions of the buildings in the study MRS. The building coverage ratio and floor area ratio were approximately $17 \%$ and $265 \%$, respectively, which did not violate the current ordinances.

The reduction in energy consumption by an advantageous building layout is closely related to the utilization of solar light. Buildings in the MRS should be arranged toward the south to maximize solar gain in winter. South-facing buildings can save $20 \%$ more heating energy than east-or west-facing buildings [51]. However, even if all buildings are arranged toward the south, the shadows of adjacent front buildings will interrupt the solar gain at the rear side of the buildings in winter. The most widely applied building layout of the MRS in Korea is a parallel building layout toward the south. If this layout is applied, a lower-floor area corresponding to $35 \%$ of the rear building cannot gain solar light between 8 am and $4 \mathrm{pm}$ in winter. Therefore, it would be desirable to arrange buildings toward the south and place them in a zigzag pattern with a solar azimuth axis of $30^{\circ}$ at 10 am and $2 \mathrm{pm}$ to gain solar light for more than four hours a day for all households during the heating season [51].

According to the landscape-related ordinances in Korea, the minimum planting space to be reserved in MRS is one-third of the lot area, which is then reduced to $15 \%$ of the lot area. As a result, although the importance of carbon offset service by trees has increased globally, the opportunity to secure a carbon uptake source in urban areas has diminished. It would be desirable to expand the planting space by amending the minimum mandatory planting area to the previous third of the lot area in MRS to enhance the carbon offset service by tree planting in urban areas. The large impervious areas in MRS should be decreased to improve tree planting by minimizing the square with no specified purpose of use and by creating underground parking, while trees should be actively planted in potential planting spaces. In the cases where it is difficult to create planting spaces within MRS, the establishment of playgrounds and resting spaces inside buildings should be encouraged, and trees should be planted outdoors. In addition, it is necessary to implement the greening of the hardscape such as roofs, walls, and fences.

A narrow planting space around the building may inhibit the normal crown and root growth of the planted trees and limit the selection of the tree species that can be planted. Based on the regression model for estimating the crown width from the tree age [52], the crown width of the planted trees (mean dbh: $13.6 \mathrm{~cm}$ ) in the study MRS was estimated to be $6.5 \mathrm{~m}$ for deciduous trees after 30 years, 
which is the approved re-construction term in Korea. However, the average width of the planting space around the building in the study MRS was approximately $2 \mathrm{~m}$, and this parameter was limited to ensure the continuous normal growth of the planted trees. It is necessary to maintain the productive growth of the planted trees to improve the performance of the carbon offset service. To supply the space for normal crown and root growth, the width of the planting space around the building should be set to more than $3 \mathrm{~m}$.

Figure 6 shows a planting design model for building energy savings in MRS. The best location for planting trees to maximize energy savings through the shading effects of trees was opposite the west and east facing walls $[16,17,22]$. Thus, the mixed planting of deciduous and evergreen trees close to the west wall of the buildings is recommended to obstruct solar gain in the afternoon during the summer. It is necessary to plant large deciduous trees in the east to block solar gain in summer mornings and secure solar gain in winter mornings. Shade tree planting in the south should be avoided because this can increase the heating energy during winter through solar gain obstruction. If the residents desire to plant trees in the south, solar-friendly trees that can transmit solar light well during the heating season should be planted. Solar-friendly trees are deciduous trees that possess relatively open crowns when out of leaf, leaf out late in spring, and drop their leaves early in the fall [16]. For the Korea, these species include: Celtis sinensis, Cornus controversa, and Ginkgo biloba [22]. The multi-layered planting of evergreen and deciduous trees in the north is recommended to maximize the annual energy savings through cold wind reduction and evapotranspiration. Along the north walls, shade-tolerant evergreen trees should be planted to minimize heat loss in the winter. In addition, to enable the use of ladder trucks, tree planting in front of balconies should be avoided.

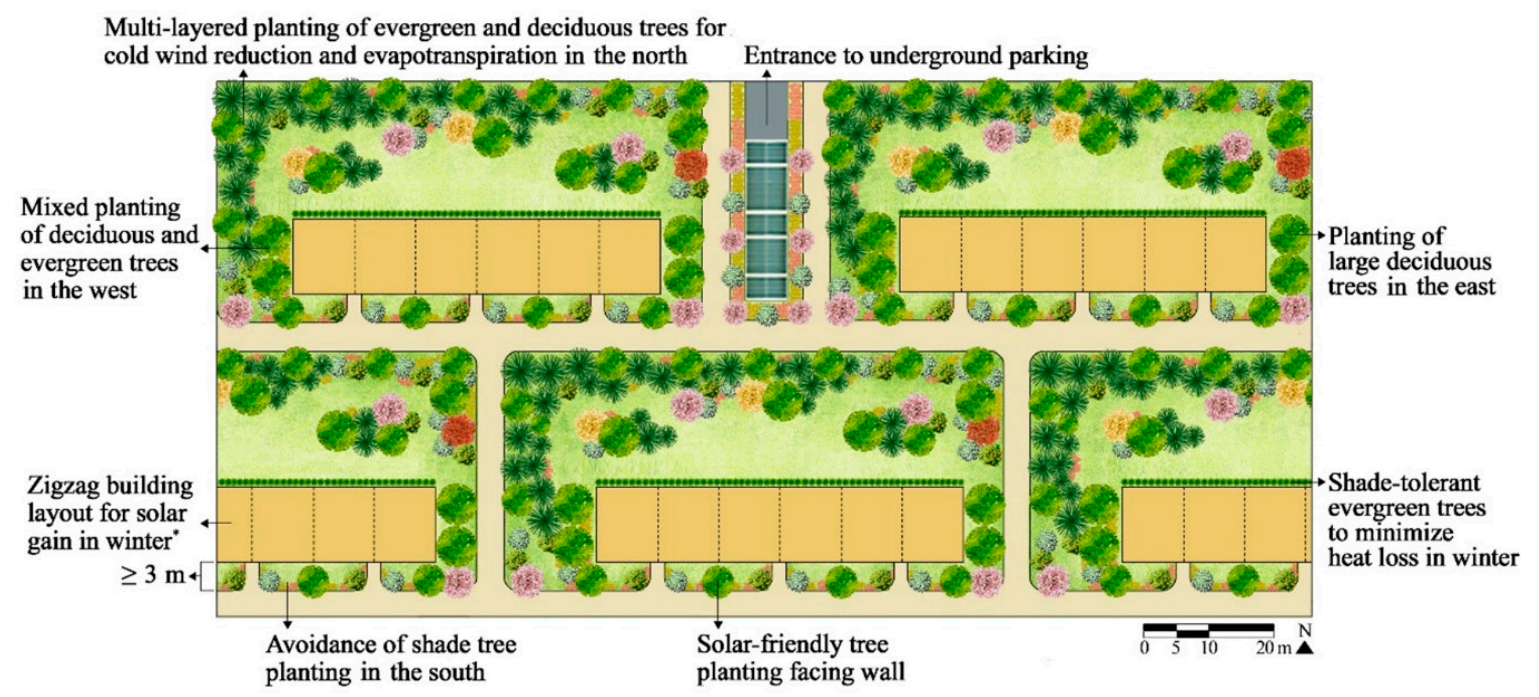

Figure 6. Planting design model for building energy savings in multifamily residential sites.

It would be desirable to apply a multi-layered and clustered planting model (Figure 7) in the large planting space of the backyard instead of single-layered planting, because multi-layered planting is more effective for obtaining the maximum tree biomass and carbon uptake per unit area [26]. The carbon uptake per unit area in multi-layered and clustered planting was approximately two times higher than that for single-layered planting [53]. The planting space of the streets should also be applied for multi-layered planting to enhance carbon offset service. It is recommended that existing mature trees be preserved instead of removed when the buildings of a MRS are constructed. In addition, this study suggests that large trees with better growth rates (e.g., Zelkova serrata, Prunus yedoensis, Pinus koraiensis) $[27,54]$ rather than small trees and tree species should be planted. 


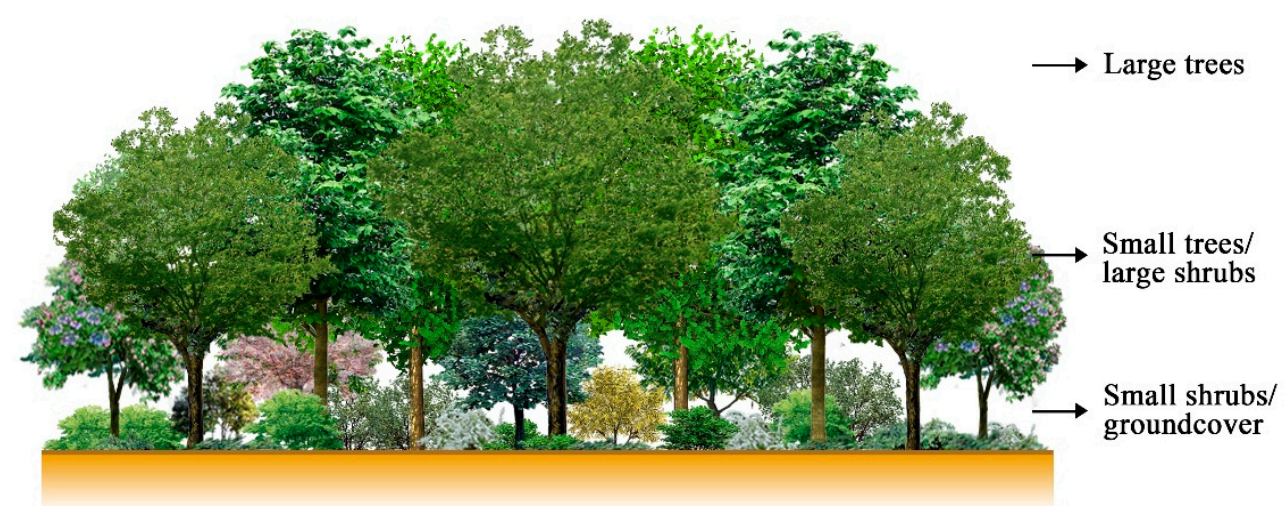

Figure 7. Section view model of multi-layered and clustered plating to enhance carbon offset service.

\section{Conclusions}

Urban trees provide an environmental and ecological service, including carbon sequestration, building energy saving, microclimate amelioration, biodiversity enhancement, and rainfall interception. In particular, urban trees play a significant role in mitigating climate change, which is a serious environmental problem globally. Since MRS, which account for the largest proportion of urban land use, are required to establish greenspaces according to current ordinances in Korea, they are the main resources for practically obtaining carbon uptake sources in cities where hardscape is dominant. However, few studies have been conducted globally on the carbon reduction quantification of trees in MRS and a desirable design to improve this service. Thus, this study quantified the building energy saving and carbon reduction of tree planting and explored sustainable design guidelines to maximize carbon offset service for MRS in Korea.

The annual direct and indirect carbon reduction by tree planting in all MRS in Korea was estimated to be approximately $101.1 \mathrm{kt} / \mathrm{year}$. The trees planted in all MRS played an important role in offsetting the annual carbon emissions from heating and cooling energy consumption in multifamily buildings by $3.3 \%$. The primary factors related to the carbon offset service level in MRS are the orientation, dimensions, density, species, and vertical structures of trees $[16,17,19,22]$. Based on such results, the design guidelines of this study include a zigzag building layout, the mixed planting of deciduous and evergreen trees in the west, the planting of large deciduous trees in the east, multi-layered planting in the north, and the avoidance of tree planting in the south.

The application of a low-carbon design and the enlargement of greenspace would not only reduce atmospheric carbon in MRS, but also improve the property value and well-being of residents. Despite the multiple services of residential trees, construction firms focus on the expansion of buildings instead of tree planting to increase profits. They establish only the minimum planting space according to the ordinances and do not plant more trees. To enhance the carbon offset service of MRS in substance, it is necessary to consider providing incentives for the construction firms to apply low-carbon designs and secure more greenspace than the ordinances require. In addition, it is important to inform the public about the multiple services of residential trees. Unlike past research, this study considered both direct and indirect carbon reduction by residential trees. This study serves as a stepping stone to acquiring indicators of carbon reduction per unit of MRS area and tree cover and is significant in that design guidelines to enhance the carbon offset service were suggested based on a detailed field survey and data collection to attain reliable results. The results of this study can be useful internationally by sharing the role and technique of sustainable residential design to maximize carbon offset service. More studies, at a regional or national scale, including DRS, are required to compare and verify the study results. Related studies about life-cycle assessments of carbon for residential trees are also needed to explore desirable maintenance decisions to improve net carbon uptake. 
Author Contributions: All authors significantly contributed to this paper. Hyun-Kil Jo was responsible for conceiving the study and the study design. Hye-Mi Park performed statistical analysis and wrote the manuscript. Jin-Young Kim contributed to the field survey and simulation.

Funding: This study was carried out with the support of the 'R\&D Program for Forest Science Technology (Project No. 2017043B10-1919-BB01)' provided by the Korea Forest Service (Korea Forestry Promotion Institute).

Conflicts of Interest: The authors declare no conflict of interest.

\section{References}

1. Stern, N. The Stern Review on the Economics of Climate Change, 1st ed.; Cambridge University Press: Cambridge, UK, 2006; pp. 14-16.

2. UNFCCC (United Nations Framework Convention on Climate Change). Greenhouse Gas Bulletin No 13; UNFCCC: Bonn, Germany, 1992; Available online: https://public.wmo.int/en/resources/library/wmogreenhouse-gas-bulletin (accessed on 15 May 2019).

3. WMO (World Meteorological Organization). Greenhouse Gas Bulletin No 14; WMO: Geneva, Switzerland, 1950; Available online: https://public.wmo.int/en/resources/library/wmo-greenhouse-gas-bulletin-no-14 (accessed on 20 May 2019).

4. NIMR (National Institute of Meteorological Research). Report of Global Atmospheric Watch 2017, 1st ed.; NIMR: Seoul, Korea, 2018; p. 1.

5. OECD (Organization for Economic Cooperation and Development). The Economics of Climate Change Mitigation Policies and Options for Global Action beyond 2012, 1st ed.; OECD: Paris, France, 2009; p. 11.

6. IEA (International Energy Agency). Key World Energy Statistics, 1st ed.; IEA: France, 2018; pp. $26-34$.

7. Angel, S.; Parent, J.; Civco, D.L.; Blei, A.; Potere, D. The dimensions of global urban expansion: Estimates and projections for all countries, 2000-2050. Prog. Plan. 2011, 75, 53-107. [CrossRef]

8. Harvey, J.; Ernie, J. Urban Land Economics, 6th ed.; Palgrave Macmillan: New York, NY, USA, 2004.

9. Statistics Norway. Land Use in Urban Settlements; Statistics Norway: Oslo, Norway, 1879; Available online: https://www.ssb.no/en/natur-og-miljo/statistikker/arealbruk/aar/2015-12-11 (accessed on 15 May 2019).

10. U.S. Department of Energy. 2011 Buildings Energy Data Book, 1st ed.; U.S. Department of Energy: Washington, DC, USA, 2012; p. 1.

11. Yu, W.; Li, B.; Lei, Y.; Liu, M. Analysis of a residential building energy consumption demand model. Energies 2011, 4, 475-487. [CrossRef]

12. UNFCCC (United Nations Framework Convention on Climate Change). Report of the Conference of the Parties Serving as the Meeting of the Parties to the Kyoto Protocol, 1st ed.; UNFCCC: Montreal, QC, Canada, 2006.

13. KFRI (Korea Forest Research Institute). A Role of Urban Forests as a Carbon Uptake Source, 1st ed.; KFRI: Seoul, Korea, 2012; p. 20.

14. Akbari, H.; Kurn, D.M.; Bretz, S.E.; Hanford, J.W. Peak power and cooling energy savings of shade trees. Energy Build. 1997, 25, 139-148. [CrossRef]

15. Akbari, H.; Davis, S.; Dorsano, S.; Huang, J.; Winnett, S. Cooling Our Communities: A Guide Book on Tree Planting and Light-Colored Surfaces, 1st ed.; U.S. Environmental Protection Agency: Washington, DC, USA, $1992 ;$ p. 34.

16. Jo, H.K.; McPherson, E.G. Indirect carbon reduction by residential vegetation and planting strategies in Chicago, USA. J. Environ. Manag. 2001, 61, 165-177. [CrossRef] [PubMed]

17. Donovan, G.H.; Butry, D.T. The value of shade: Estimating the effect of urban trees on summertime electricity use. Energy Build. 2009, 41, 662-668. [CrossRef]

18. Haggag, M.; Hassan, A.; Qadir, G. Energy and economic performance of plant-shaded building façade in hot arid climate. Sustainability 2017, 9, 2026. [CrossRef]

19. Jo, H.K.; Han, G.S.; Seo, O.H. Function of energy saving and carbon emission reduction by urban vegetation-case of Chuncheon. J. Korean Inst. Landsc. Archit. 1998, 26, 104-117.

20. Nowak, D.J.; Appleton, N.; Ellis, A.; Greenfield, E. Residential building energy conservation and avoided power plant emissions by urban and community trees in the United States. Urban For. Urban Green. 2017, 21, 158-165. [CrossRef]

21. Panahiana, M.; Ghoshb, S.; Ding, G. Assessing potential for reduction in carbon emissions in a multi-unit of residential development in Sydney. Procedia Eng. 2017, 180, 591-600. [CrossRef] 
22. Jo, H.K.; Jo, Y.H. Ecological Landscape Planning and Design, 2nd ed.; Kimoondang: Seoul, Korea, 2008; pp. 282-286.

23. KOSIS (Korean Statistical Information Service). Available online: http://kosis.kr/statHtml/statHtml.do? orgId=315\&tblId=TX_315_2009_H1501\&vw_cd=MT_ZTITLE\&list_id=315_31502_016\&seqNo=\&lang mode $=$ ko\&language=kor\&obj_var_id=\&itm_id=\&conn_path=MT_ZTITLE (accessed on 21 May 2019).

24. MOLIT (Ministry of Land Infrastructure and Transport). Available online: http://stat.molit.go.kr/portal/cate/ statView.do?hRsId=327\&hFormId=5403\&hSelectId=5727\&hPoint=1\&hAppr=1\&hDivEng=\&oFileName $=$ \&rFileName=\&midpath=\&month_yn=N\&sFormId=5403\&sStart=2018\&sEnd=2018\&sStyleNum=1\& sDivEng=N\&EXPORT $=$ (accessed on 21 May 2019).

25. Ministry of Government Legislation. Available online: http://www.law.go.kr/lsInfoP.do?lsiSeq=208473\& efYd=20190423\#0000 (accessed on 10 April 2019).

26. Jo, H.K. Impacts of urban greenspace on offsetting carbon emissions for middle Korea. J. Environ. Manag. 2002, 64, 115-126. [CrossRef]

27. Jo, H.K.; Kim, J.Y.; Park, H.M. Carbon reduction and planning strategies for urban parks in Seoul. Urban For. Urban Green. 2019, 41, 48-54. [CrossRef]

28. Jo, H.K.; Cho, D.H. Annual $\mathrm{CO}_{2}$ uptake by urban popular landscape tree species. J. Korean Inst. Landsc. Archit. 1998, 26, 38-53.

29. Jo, H.K. Indicator for $\mathrm{CO}_{2}$ Uptake and Atmospheric Purification Evaluation of Vegetation, 1st ed.; Ministry of Environment: Seoul, Korea, 2001.

30. Jo, H.K. Development of Model and Technology for Establishment, Management and Evaluation of Urban Forests in Living Zone to Improve Carbon Sequestration Sources and Multi-Dimensional Benefits against New Climate Change Regime, 1st ed.; Korea Forest Service: Daejeon, Korea, 2017.

31. Jo, H.K.; Ahn, T.W. Annual $\mathrm{CO}_{2}$ uptake and atmospheric purification by urban coniferous trees: For Pinus densiflora and Pinus koraiensis. Korean J. Environ. Ecol. 2001, 15, 118-124.

32. Jo, H.K.; Ahn, T.W. Carbon storage and uptake by deciduous tree species for urban landscape. J. Korean Inst. Landsc. Archit. 2012, 40, 160-168. [CrossRef]

33. Jo, H.K.; Kim, J.Y.; Park, H.M. Carbon storage and uptake by evergreen trees for urban landscape for Pinus densiflora and Pinus koraiensis. Korean J. Environ. Ecol. 2013, 27, 571-578. [CrossRef]

34. Jo, H.K.; Kim, J.Y.; Park, H.M. Carbon reduction effects of urban landscape trees and development of quantitative models: For five native species. J. Korean Inst. Landsc. Archit. 2014, 42, 13-21. [CrossRef]

35. MOLIT (Ministry of Land, Infrastructure, and Transport). Personal Communication; MOLIT: Sejong, Korea, 2019.

36. KEEI (Korea Energy Economics Institute). Yearbook of Energy Statistics, 1st ed.; KEEI: Ulsan, Korea, 2017.

37. KEEI (Korea Energy Economics Institute). 2017 Energy Consumption Survey, 1st ed.; Ministry of Trade, Industry \& Energy: Sejong, Korea, 2018.

38. Korea City Gas Association. Available online: http://www.citygas.or.kr/info/stats/read.jsp?reqPageNo=1\& sbranch_fk=2\&no=309 (accessed on 10 April 2019).

39. MOLIT (Ministry of Land, Infrastructure, and Transport). Available online: http://stat.molit.go.kr/portal/ cate/statView.do?hRsId=33\&hFormId=760\&hDivEng=\&month_yn= (accessed on 19 May 2019).

40. KECO (Korea Environment Corporation). Guidelines for Local Government Greenhouse Gas Inventories, 1st ed.; KEC: Incheon, Korea, 2016.

41. ME (Ministry of Environment). National Greenhouse Gas Inventory Report of Korea, 1st ed.; ME: Sejong, Korea, 2018; pp. 87-88.

42. Kim, G.W. Assessing urban forest structure, ecosystem services, and economic benefits on vacant land. Sustainability 2016, 8, 679. [CrossRef]

43. Rumble, H.; Rogers, K.; Doick, K.J.; Hutchings, T. A comparison of urban tree populations in four UK town and cities. In Trees, People and the Built Environment II; Johnston, M., Percival, G., Eds.; Institute of Chartered Foresters: Edinburgh, UK, 2015.

44. Daniel, C.; Morrison, T.H.; Phinn, S. The governance of private residential land in cities and spatial effects on tree cover. Environ. Sci. Policy 2016, 62, 79-89. [CrossRef]

45. Jo, H.K.; Lee, K.E.; Yun, Y.H.; Seo, O.H. Land use and greenspace structure in several cities of Kangwon Province. J. Korean Inst. Landsc. Archit. 1998, 25, 171-183. 
46. Jo, H.K.; Ahn, T.W. Structural conditions of greenspace in a rural region and strategies for its functional improvement: In the case of Yanggu, Gangwon Province. Korean J. Environ. Ecol. 2006, 20, 493-502.

47. Korea City Gas Association. Available online: http://www.citygas.or.kr/info/charge.jsp (accessed on 15 April 2019).

48. Korea Electric Power Corporation. Available online: http://cyber.kepco.co.kr/ckepco/front/jsp/CY/E/E/ CYEEHP00101.jsp (accessed on 15 April 2019).

49. GCCSI (Global Carbon Capture and Storage Institute). Global Costs of Carbon Capture and Storage, 1st ed.; GCCSI: Melbourne, Australia, 2017.

50. IEA (International Energy Agency). Electricity Information 2014, 1st ed.; IEA: Paris, France, 2014.

51. Lee, Y.M. Site Planning Techniques for Resource Saving, 1st ed.; Kimoondang: Seoul, Korea, 1991.

52. CAER (Center for Aquatic Ecosystem Restoration). Development of Technology to Establish Riparian Greenspace and Eco-belt, 1st ed.; Ministry of Environment: Sejong, Korea, 2018.

53. Jo, H.K.; Park, H.M. Effects and improvement of carbon reduction by greenspace establishment in riparian zones. J. Korean Inst. Landsc. Archit. 2015, 43, 16-24. [CrossRef]

54. Jo, H.K.; Park, H.M. Changes in growth rate and carbon sequestration by age of landscape trees. J. Korean Inst. Landsc. Archit. 2017, 45, 97-104.

(C) 2019 by the authors. Licensee MDPI, Basel, Switzerland. This article is an open access article distributed under the terms and conditions of the Creative Commons Attribution (CC BY) license (http://creativecommons.org/licenses/by/4.0/). 